\title{
The Role of International Organization for Migration in Handling Human Trafficking in Sambas Regency, West Kalimantan Province
}

\author{
Nurfitri Nugrahaningsih \\ Department of International Relations, Universitas Tanjungpura, Pontianak, Indonesia \\ nurfit_nn@yahoo.com
}

\section{Hardi Alunaza}

Department of International Relations, Universitas Tanjungpura, Pontianak, Indonesia hardi.asd@fisip.untan.ac.id

\section{Ratu Zahirah Lutfie}

Department of International Relations, Universitas Tanjungpura, Pontianak, Indonesia ratu_lutfie@yahoo.com

Submitted: 22 January 2020; Revised 20 June 2020; Accepted: 22 July 2020

\begin{abstract}
Abstrak
Perdagangan manusia menjadi isu sentral di era globalisasi karena mewabah di berbagai negara. Kasus perdagangan manusia sudah marak sejak lama di Indonesia, bahkan di beberapa daerah seperti Nusa Tenggara Timur, Kalimantan Timur, Nusa Tenggara Barat, dan Kalimantan Barat, ini merupakan fenomena rentan. Provinsi Kalimantan Barat menduduki peringkat kedua tertinggi kasus perdagangan manusia di Indonesia, khususnya di Kabupaten Sambas yang berbatasan langsung dengan Malaysia. Makalah ini bertujuan untuk mendeskripsikan peran IOM dalam menangani kasus perdagangan manusia di Kabupaten Sambas, Kalimantan Barat. Penelitian ini menggunakan pendekatan kualitatif dengan pola penulisan deskriptif, yang sumber datanya berdasarkan tinjauan pustaka dan studi lapangan melalui wawancara dengan IOM dan pemerintah daerah Kabupaten Sambas. Organisasi internasional dan teori liberalisme institusional digunakan untuk menganalisis fenomena tersebut. Hasil dari penelitian ini menunjukkan bahwa IOM menjalankan peran dan fungsinya dengan bekerja sama dengan pemerintah daerah dalam melakukan sosialisasi dan melibatkan pemerintah baik secara vertikal maupun horizontal. IOM juga melakukan reintegrasi dan pendampingan korban. Selain itu, IOM melakukan proses penemuan dari segi ekonomi dan sosial. Keberadaan IOM dapat menjadi mitra yang tepat bagi pemerintah dalam menangani perdagangan manusia. Dengan demikian, kerjasama dan dukungan untuk pelaksanaan kebijakan pemerintah dapat diwujudkan.
\end{abstract}

Kata Kunci: perdagangan manusia, keamanan manusia, organisasi internasional

\begin{abstract}
Human trafficking becomes a central issue in the globalization era for being an epidemic in various countries. Cases of human trafficking have been rife for a long time in Indonesia, even in some areas such as East Nusa Tenggara, East Kalimantan, West Nusa Tenggara, and West Kalimantan, this phenomenon is vulnerable. West Kalimantan Province has ranked second highest in human trafficking cases in Indonesia, particularly in Sambas Regency, an area directly adjacent to Malaysia. This paper aimed to describe the role of IOM in tackling human trafficking cases in Sambas Regency, West Kalimantan. This study utilized a qualitative approach with descriptive writing patterns, and data sources were based on literature review and field studies through interviews with IOM and the local government of Sambas Regency. International organizations and institutional liberalism theories were employed to analyze the phenomenon. The results revealed that IOM performed its role and function by cooperating with the local government in conducting socialization and involving the government both vertically and horizontally. IOM also conducted reintegration and victim assistance. Moreover, IOM carried out discovery processes in economic and social terms. The existence of IOM can be the right partner for the government in dealing with human trafficking. Thereby, cooperation and support for the implementation of government policies can be established. Keywords: human trafficking, human security, international organizations
\end{abstract}




\section{INTRODUCTION}

The issue of global security is currently receiving particular attention to each country. Moreover, this issue is not only related to state security but also directly deals with human security. Being the center of the world's attention, human trafficking is viewed as a crime endangering human security (Winarno, 2011). Human trafficking crime is an act involving recruitment, transportation between regions or across countries, transfer of hands, departure, threats or physical or verbal violence, kidnapping, fraud, sexual exploitation, and the prostitution industry (Rudy, 2003). Human trafficking cases frequently occur in countries experiencing weak economic growth, such as those in the Asia Pacific region, especially developing countries such as Indonesia (Atem, 2017). The United Nations identified 18 forms of transnational crime, and one of which is human trafficking (Widowaty, 2015).

Human trafficking becomes a central issue in this globalization era for being an epidemic in various countries. It deals not only with criminal acts but also violations of human rights. Thus, understanding human rights is necessary as humans have the right to live with dignity and free from forms of exploitation and crime. Cases of human trafficking have been rife for a long time in Indonesia, even in some areas, such as West Java, East Nusa Tenggara, East Java, East Kalimantan, West Nusa Tenggara, and West Kalimantan, such a phenomenon is vulnerable (Secretariat of Prevention Task Force and Handling of TPPO, 2018). The causes of widespread human trafficking are low access to the education sector, poverty, prostitution, and lifestyle (Niko, 2018). Every year, there are hundreds of human trafficking victims in West Kalimantan, placing this province the second among 12 highest human trafficking regions, with 722 cases or 19.33\% (Wismayanti, 2012).

West Kalimantan is an area with land borders intersecting directly with Malaysia, making it vulnerable to various transnational crimes, including human trafficking. One of the border areas is Sambas Regency. Human trafficking crimes recorded and handled by the Integrated Service Center for the Empowerment of Women and Children (P2TP2A) of West Kalimantan
Province to August 2010 reached 137 people with 30 cases, coming in second after West Java (P2TP2A, 2018).

Data on human trafficking in Sambas Regency from 2016 to 2018 continued to increase. Eight human trafficking cases were handled and resolved by Sambas Regional Police in 2018. This phenomenon was dominated by human trafficking and prostitution abroad. Sambas Regency, directly adjacent to a neighboring country, can become an area for human trafficking in and out of West Kalimantan. It is influenced by the number of the labor force not proportional to the number of available jobs, the location of West Kalimantan directly adjacent to East Malaysia, differences in the economic level, easy access to neighboring countries, weak population administration system, and lack of appropriate information about the fieldwork abroad (Gunawan, 2018). There have been 125 human trafficking cases occurring in Sambas Regency since 2009. The regions being the center of human trafficking are Teluk Keramat, Sambas, Jawai, Pemangkat, Tebas, Tangaran, Dariung, and Sajad Districts (Sutan, 2016).

To provide human security, important actors play a role in this matter, both state and non-state. The state becomes an actor with a very influential power in protecting to create security. However, this role is also not necessarily only performed by state actors, given that the security problems seen from the occurrence of human trafficking cases are complex. Therefore, it is necessary to involve other relevant actors in their fields, one of which is an international organization. The International Organization for Migration (IOM) is one of the international organizations working under the cooperation of the United Nations, explicitly handling human trafficking. Data on human trafficking cases occurring in Sambas Regency are a clear example of the perspective of a new security dimension emerging amid international relations developing in the current globalization era. Globalization has facilitated the rotation and movement of people, the economy, and even crime (Alunaza, 2016).

Therefore, as an international organization, IOM is expected to contribute and coordinate with the 
government in efforts to handle human trafficking. Through its role, IOM fights for human rights, especially migrant workers experiencing exploitation. The high number of human trafficking cases in Sambas Regency is inseparable from its strategic geographical influence, causing the placement of IOM representatives in this area. This study investigated the extent of the IOM representative role in handling human trafficking in the area. IOM is viewed as an international organization working and helping the government to fight against human trafficking. Therefore, the role of IOM is significant as it can influence and support government policy.

The data above indicate that human trafficking crimes require equal attention from academics and stakeholders, especially in the region. Handling human trafficking victims is not easy and cannot be done in a short time. It requires a long and ongoing process. Efforts to prevent and deal with it successfully depend on the commitment of local government policymakers in Sambas Regency.

Concerning this issue, several previous studies have discussed the role of IOM as follows:

1. IOM's role in overcoming human trafficking in Indonesia (2010-2014) by Ghani Wal Arif in 2016 focused on the discussion of the IOM's role in general, analyzed using the theory of international organizations (Riau University).

2. IOM's role in overcoming human trafficking in Indonesia by Alif Oktavian et al. from Pasundan University in 2018, focusing on the discussion on legal instruments and enforcement, and spreading the role as a partnership of government and NGOs, especially strengthening law enforcement in the case. The theories used were international organizations, the concept of human trafficking, and international migration.

3. A study entitled "Analysis of the IOM's Roles in Handling Human Trafficking in Indonesia based on the Humanitarianism Principles" by Tri Robbiul Asfa in 2017 from Andalas University
This research is the continuation of previous studies aiming to determine the role of IOM in handling human trafficking in Sambas Regency based on its function as an international organization. It is a case study examining the presence of the IOM representative placed in Sambas Regency. This paper emphasizes five points of IOM's operational functions, namely, articulation, aggregation, socialization, recruitment, and transaction in handling human trafficking occurring in Sambas Regency from 2018 to 2019.

\section{LITERATURE REVIEW INSTITUTIONAL LIBERALISM}

The birth of the liberalism paradigm led to the direction of peace and changed the order of the previously anarchist international system toward world peace by promoting inter-actor cooperation. Trough this paradigm, forms of liberalism emerge. According to Robert Jackson and Georg Sørensen, liberalism is divided into four types, sociological, interdependent, institutional, and republican (Jackson \& Sørensen, 2013). The institutional liberalism theory states that international institutions help promote cooperation between countries (Jackson \& Sørensen, 2013). The emergence of views on the importance of institutions aims to reduce distrust in an established partnership. Moreover, institutional liberalism, according to liberals, is an international organization having a set of rules governing state actions in specific fields (Meiser, 2018). This term is also referred to as "the regime" in regulating trade and maritime law.

If the international system was previously more anarchic and bipolar by only promoting cooperation between the two countries, the emergence of institutional liberalism raised multipolar creating cooperation among actors based on the existence of international organizations. According to the adherents of realism John Mearsheimer, anarchy has two fundamental consequences. First, there is little room for trust between countries. Second, each country must guarantee its survival since there are no other actors providing security. According to institutional liberalism, the role of institutions is to provide information flow and 
negotiation opportunities, improve the ability of governments to monitor other forces as facilitators, and implement their commitments giving rise to mutual trust and making international agreements (Meiser, 2018).

International institutions help promote cooperation between countries and therefore reduce distrust between states and the fear of one another in what is considered to be a traditional problem associated with international anarchy (Jackson \& Sørensen, 2013). Hence, countries will know more about the goals and what other countries will do by joining international institutions due to mutual openness. Therefore, other cooperation arises in the members of the international institution, both bilateral and multilateral.

\section{INTERNATIONAL ORGANIZATION THEORY}

According to Karen Mingst, international organizations are defined as international agencies or agencies formed and controlled by several countries based on the collective interests of these countries (Ambarwati, 2016). Meanwhile, international organization can be defined as a formal, continuous structure established by agreement between members (governmental and/or non-governmental) from two or more sovereign states with the aim of pursuing the common interest of the membership (Archer, 2001).

International organizations are formal institutions formed by two or more countries and have goals, mobility, and actions transcending the national boundaries of a country and controlled by its members based on agreements jointly determined and collective interests. Whereas Wallace and Singer (1970) stated, "The organization 'must consist of at least two qualified members of the international system... and should have been created by a formal instrument of agreement between the governments of national states." Wallace and Singer also mention that international organizations have at least a secretariat or permanent central office arrangements and carry out ongoing and established tasks (Archer, 2001).

In other words, an international organization can consist of two or more members of a country and have fulfilled the requirements or conditions based on the applicable international system or law. International organizations are also formed through official agreements by the governments of the countries concerned and have a central secretariat in carrying out assigned tasks regarding the interests of the organization and coordinating all actions of the organization.

International organizations are also formed to achieve their interests. According to Harold Jacobson, there are five objectives held by international organizations, namely: (1) International organizations present information related to the interests of their members; (2) International organizations set standards of behavior and norms; (3) International organizations set rules binding to their members; (4) International organizations can also act as supervisors of the determined rules; (5) International organizations act as parties providing services and programs to their members or other organizations members of the international community (Ambarwati, 2016).

There are several types or classifications of international organizations such as regional or international, intergovernmental (international government organizations) formed based on cooperation and government agreements of several countries, and international non-government organizations formed without interference or agreement from the official government and is independent. Moreover, a transnational organization (TGO) is defined as an organization in which one of the parties does not come from a government agency and can be a non-state actor. Therefore, transnational organizations are formed from members officially institutionalized, but one of its members is not a representative of the government or state (Ambarwati, 2016).

\section{OPERATIONAL FUNCTIONS OF INTERNATIONAL ORGANIZATIONS THEORY}

International organizations are one of the actors in international relations, paying particular attention to interactions between countries and non-state actors in a structure having a specific function. International organizations have never been formed to fight or oppose each other. In a broad sense, this international 
organization can be interpreted as an engagement between subjects crossing national boundaries based on an agreement and have joint organs (Ikbar, 2014). According to Michael Haas, international organizations have two functions, input and output. The input function involves government agencies in the domestic political system. This function consists of articulation, aggregation, socialization, recruitment, and transactions. Conversely, the output function includes making, implementing, and monitoring rules. Each of these functions should be applied to assess the extent of the performance of an international organization (Haas, 1965).

\section{Articulation Function}

The function of articulation is defined as a statement of demands on domestic and international political systems. Internationally, relevant demands can be voiced by individuals and groups, the private sector, stakeholders, and international non-governmental organizations through spokespersons at the local, regional, and international levels. The articulation function can occur in forums, such as meetings, conferences, negotiations, and meetings conducted by the General Assembly of the United Nations (UN). The international system and organizations differ according to the rules of membership, the number of member units, and the demographic homogeneity of the units. Each unit can articulate its demands legally. However, several roles require specialization or division of labor, depending on the field, such as industry, agrarian, and organizations engaged in the field of humanity, both with large, medium, and small powers that will focus their demands on the most vital issues for articulation (Haas, 1965).

However, articulation by non-governmental actors is sometimes ignored, and it is precisely the demands of stakeholders making decisions on behalf of their institutions in government more often heard. Therefore, some sub-national groups, such as the United States Chamber of Commerce and cross-country associations in practice sometimes depend on the government rather than standing independently in international relations because of the interest in articulating their demands can be easily listened to by the government. The types of institutions articulating demands vary greatly, ranging from royal governments, dynastic states, nation-states, and other actors recognized as legitimate participants in international conferences or other formal inter-unit meetings (Haas, 1965).

\section{Aggregation}

The aggregation function occurs if the demands of several units are combined and harmonized to reduce inter-unit inconsistencies, and are collectively trusted as a whole. As a function of aggregation of interests, it combines various demands and makes efforts to reduce the gap between the various existing units. Aggregation involves cooperation in articulating demands by two or more political system units. It can be performed from the level of ambassadors agreeing, and then the agreement is formalized into a written agreement form to the formation of alliances or groups of international organizations. Such an agreement is an example of the structural effect of the aggregation function (Haas, 1965).

At the international level, the aggregation function is usually formed informally. However, this step can result in the formation of a systematically structured institutional framework. Although some elements playing a role in the aggregation of interests frequently have different goals, other elements can act as intermediaries setting boundaries where aggregation can be continued or stopped. This function is carried out by government decision-makers on behalf of their units in the international political system. However, autonomous leaders from intergovernmental organizations can also encourage aggregation among countries through behind-the-scenes negotiations, as can the Secretary-General of the United Nations (Haas, 1965).

The stratification of international forces can explain patterns of aggregation. In a hierarchical system, there are primary and secondary interests. The presence of these two types of interests aims to achieve a balance to satisfy both interests. Aggregation can be carried out by leaders of power blocks to ensure the solidarity and strength of their blocks. In this case, the Ministry of Foreign Affairs 
of each country plays a dominant role in the aggregation strategy. In a loose block of power, the role of international actors can be successful in accommodating cross-bloc interests, while not aligned parties or countries will try to reach a position mediated by opposing blocs (Haas, 1965).

When the bipolarity system in the world loosens, international organizations begin to be used as an aggregation arena. The institutionalized aggregation will fade when the big powers can no longer fix the disputes between them. Conversely, as long as there is no intensive power struggle between members of multipolar and multi-aligned systems, aggregation occurs at a low speed. When the number of inter-unit transactions in the world increases, it is more likely for an institutional framework to carry out its aggregation functions. Therefore, aggregation is carried out by government units, especially those playing the role of mediator or leadership in international governance. The functional specificity of institutions in aggregation decreases because power is distributed more evenly in the world (Haas, 1965).

\section{Socialization}

According to Michael Haas, the type of socialization is divided into two. The first type of socialization refers to the process of learning what roles one should do, and what patterns of behavior should be followed. Meanwhile, the second type of socialization occurs when decision-makers attempt to direct their countries in various roles at the level of the world government. Moreover, they also study the obstacles that might occur and prepare themselves to overcome them. Furthermore, Haas states that participation in international organizations can also be one form of outward-oriented socialization, and seeks to modify the narrow particularistic behavior possessed by actors in the system (Haas, 1965).

In strict bipolarity, inward-oriented socialization tends to be used to study the ideological interests and advantages of blocks opposite to each other. Both inward-oriented and outward-oriented socialization in multipolar systems are particularistic, but some forms of outward-oriented outreach can reshape the international system through joint consultations and decisions. In the international system, universal organizations require an outward-oriented level of international outreach within their institutional framework (Haas, 1965).

\section{Recruitment}

The recruitment function of international organizations is used to invite or attract participants, both directly and indirectly, in achieving interests. In the international political system, the organization's recruitment process can be direct, i.e., carried out by the organization concerned to the audience or participants face-to-face and in a persuasive manner. It aims to invite the audience to join the organization (Haas, 1965).

The second recruitment process is indirectly carried out by involving third parties acting as intermediaries. These intermediaries can be in the form of goods or people. For example, in the contemporary era, such as today, economic superiority has raised nation-states such as Canada, Japan, and Germany to leadership roles and the military inferiority in economic organizations, such as the G-20 (Haas, 1965), meaning the economy has become a third party in the means of recruitment between countries and international organizations.

\section{Transaction}

Transactions can be interpreted as activities involving the exchange of symbols, goods, or people between one actor and another. In international relations, trade and exchange of citizens are as vital as communication, transmission, and reception of messages. In the domestic system, trade and travel are forms of activities representing economic and cultural symbols of a social system. Thus, it can be separated from the political party of a social system. However, international relations are highly politicized, making it difficult to ignore international trade, labor mobility, and cultural exchange in analyzing the functions of the international political system (Haas, 1965).

World governments can be distinguished based on the level of interaction between units. In ancient civilizations, there was little interaction between the 
empires. In modern times, the interaction between two or more actors is so frequent that international organizations must facilitate universal membership. In the past, for ordinary people, information about what happened in other countries might not be something essential to know. However, it is not so in the view of the country's elite government. Therefore, transactions of symbols, people, and goods began to occur in the meetings of international organizations, both conference rooms and along the corridors of the central offices of these agencies and other technical assistance agencies of these organizations. International organizations, through their secretariats, contribute a large number of international transactions with publications, political activities, and technical services (Haas, 1965).

\section{RESEARCH METHOD}

This study on the role of local government in overcoming human trafficking in Sambas Regency, West Kalimantan, is descriptive research with a qualitative approach, in which the author tries to provide an overview or describe the state of objects and existing problems (Sugiyono, 2011). Therefore, the use of the descriptive method was expected to define the facts and characteristics of the studied object appropriately. The data collection techniques employed were library studies, field studies through observations, interviews, and documentation.

Both primary (interview results with informants) and secondary data (literature studies) were sorted according to IOM's role in handling human trafficking and analyzed using the theory of international organizational functions proposed by Michael Haas. Researchers conducted research in Sambas Regency, specifically at the Regent's Office, Aruk Cross Country Post (PLBN), Indonesian Workers Placement and Protection Service Post (P4TKI), One-Stop Integrated Services Placement and Indonesian Worker Protection (LSTA P2TKI), Police Station, Office of Empowerment Women, Child Protection, Population and Family Planning Control (P3AP2KB), and IOM Sambas Representative Office. The research also took place in Jakarta at IOM Indonesia Headquarters. The authors conducted the validity process with source triangulation techniques referring to literature sources and interview results (Sugiyono, 2015). In this study, data analysis techniques referred to the Miles and Huberman-style analysis models consisting of data collection, data reduction, data presentation, and drawing conclusions (Sugiyono, 2015).

The data obtained through interviews dealt with the number of human trafficking victims, Sambas Government policies in handling such a crime, population data in and out of Sambas Regency, human trafficking victims assistance, victims, IOM's policy in reintegrating and victim assistance, and the discovery process in economic and social terms. Data collected from the interviews with informants and literature studies were then selected following the IOM's role in dealing with human trafficking in Sambas Regency.

\section{RESULT AND DISCUSSION}

\section{THE ROLE OF INTERNATIONAL ORGANIZATION FOR MIGRATION IN HANDLING HUMAN TRAFFICKING IN SAMBAS REGENCY, WEST KALIMANTAN PROVINCE}

Having a strategic location directly adjacent to Sarawak Malaysia makes Sambas the central mobilization location, especially for workers and migrants who will work abroad through the Aruk Cross-Border Post (PLBN). This condition then made Sambas Regency one of the areas with a high level of human trafficking (TPPO), causing the IOM to establish its representatives in Indonesia. It indicated the crucial role of the IOM in Sambas Regency, representing the function of international organizations, namely the articulation function of interests to express aspirations or demands in the domestic and the international political system. According to one of the IOM representatives in Sambas Regency, the organization's role is as a forum for coordination supporting efforts to improve services to strengthen the task force and the efforts of legal aid agencies to handle victims (Musta'im, Personal Communication, October 2, 2019). In achieving its objectives in protecting trafficking victims, IOM seeks to supervise and implement the established rules. The role of IOM in coordinating efforts and supporting the role of task forces in dealing with 
human trafficking becomes an effort to tackle the problem. Moreover, IOM has been engaged as supervision and implementation. Based on the field study, IOM's oversight role was still invisible because it focused more on assisting victims.

The function of IOM is to articulate its interests in carrying out its objectives in the supervision and application of government rules. However, in its application, there was still a sectoral ego making the IOM function did not work well. The presence of IOM's representative in the regency was also minimal. It was conveyed by IOM Sambas representative that:

"For now, it is still part of the BP2A and holds one seat. There used to be a provincial representative office in Pontianak that had previously focused on handling conflict by helping victims, but now it concentrates on immigrants. The number of immigrant workers in 2019 was 23,000 people, and usually, in a year, 40,000 immigrant workers pass through the Aruk PLBN. Representatives distributed IOM in three regencies such as Sambas, Sanggau, and Badau (Kapuas Hulu).” (Musta'im, Personal Communication, October 2, 2019).

One of the operational functions of international organizations is as a means of aggregation of interests combining various demands and making efforts to harmonize to reduce the gap between the various existing units. IOM's function as an effort to strengthen government institutions is achieved by coordinating with the task force. As stated earlier, this TPPO task force consists of all stakeholders in the Sambas Regency government. Therefore, the aggregation function of the IOM's interests is an effort to harmonize to avoid gaps in the units in the task force. It is supported by opinions expressed by representatives of IOM in Sambas Regency stating, “...according to the notification letter that IOM's duties are clear and have been stated in a letter (formal agreement), which is also used to support the handling of human trafficking victims" (Musta'im, Personal Communication, October 2, 2019).

The statement above shows that the IOM's role as an international organization in its efforts to tackle human trafficking is to provide support. It is intended to align the role of government through the task force formation. Furthermore, (Musta'im, Personal Communication, October 2, 2019) also mentioned that:

"At the end of 2018, IOM's task was to facilitate the Local Government to strengthen the TPPO Task Force, and there was a licensing officer to bridge and protect the institution. This facility was provided in the form of service improvement carried out through victim handling to the court stage, assisting victims, such as legal assistance, in collaboration with the Legal Aid Institute. Medical assistance when conducting a post mortem until in the reintegration or empowerment stage."

The interview results revealed that IOM has carried out an interest aggregation function as an effort to align interests by bridging and nurturing institutions, thereby each institution understands their respective duties. Moreover, these efforts aim to facilitate each of the relevant institutions by assisting the victims of human trafficking. However, this effort could not be fully applied because there was still no strong synergy from IOM and the task force existing in the ranks of the Regional Government. On the other hand, the task of the government through the task force is to implement existing policies, while the IOM supports and oversees the task force's performance. However, coordination problems remain to exist since the Regional Government's assumptions are sometimes viewed as devolving responsibility to IOM (Musta'im, Personal Communication, October 2, 2019). In conclusion, the function of IOM in aggression cannot be performed optimally due to obstacles in the implementation of existing policies.

IOM's role in carrying out its function as an international organization, especially concerning human trafficking, can be seen from its efforts in coordinating with the government. It was proven by the statement of Hendy as the Head of the Office for Empowerment of Women and Children Population Family Planning (BP3AP2) in Sambas Regency:

"... we are also in a relationship with IOM. So, IOM has about two years of the project here. They also conduct research here, aiming to strengthen the task 
force. As we know that IOM is also a ministerial facilitator because it is under the auspices of the United Nations, which indeed concentrates on the trafficking field ..." (Hendy, September 10, 2019).

The explanation above implies that IOM has helped strengthen the task force of the Sambas Regency government. Therefore, IOM's role is not only as an observer but also as a liaison between government agencies in handling human trafficking. Besides, IOM also conducted research projects in Sambas for the next two years. The Sambas government also recognizes the role of IOM in its participation in helping to handle human trafficking cases. Hairiah, the Deputy Regent of Sambas Regency, supported such a notion by stating:

"...there is coordination with IOM, specifically for trafficking ... but previously, they were more focused on research with Universitas Gadjah Mada and supported casuistically. Therefore, if there were trafficking cases, they would help support, and they would provide training for law enforcement officers or the police to handle victims of trafficking." (Hairiah, Personal Communication, July 31, 2019).

The above statement shows the synergy of IOM and the government in creating integration and solidity in preventing trafficking. There are coordination and support from IOM to the Sambas government in the form of research with academics and training to the authorities in strengthening or enhancing capabilities related to the better and more appropriate prevention and handling of trafficking cases. The presence of IOM here is undoubtedly needed to provide further understanding, analysis, and support in handling and the government decision-making process.

Through this predetermined program, the role of IOM as an international organization has been clear and focused specifically on issues of immigration and human trafficking. Therefore, a synergy between IOM and stakeholders is required. Moreover, the IOM representative also said that:

"In handling the initial case, we have a case record, a deepening of the case, and obtaining complete information is what I did to one of the victims in Jawai. Therefore, I have gone back and forth several times to Jawai. It should be the role of $\mathrm{BP} 2 \mathrm{~A}$, it should be done with the task force, but due to their busy schedules, so I handled it. For these four cases, as I say, there are many motives. The one in Salatiga has withdrawn his report. At present, two cases are being assisted and are still running, while that one case in Jawai cannot be processed deeper because the information obtained from the victims is still incomplete. It is also a form of slow government response because the data need to be completed in all stakeholders." (Musta'im, Personal Communication, October 2, 2019).

The existence of regulations governing TPPO should be the basis to prevent and handle human trafficking cases. Therefore, the functions of IOM as an international organization in aggregating interests are performed through demands and assisting alternative programs that have been established, and strengthening the task force. Furthermore, the delivery of the IOM program to the task force is the basis for making rules, and thereby, the task force will understand their duties in the field. In this case, IOM is also an alternative provider of support to the Sambas government in establishing policies or solving human trafficking problems.

It is undeniable that in the effort to implement policies, socialization is required as a form of learning and providing information to related parties. Thus, existing policies can be appropriately implemented. It is also an essential function of IOM, which is policy socialization. As one of the government organizations, IOM certainly has its programs to strengthen institutions in the task force. An IOM representative said, “... usually the community reports directly to the police, not to the service or task force, even though based on the mechanism there have been pamphlets installed in the district through the task force" (Mustafa, October 2, 2019).

Since its establishment as a regency representative at the end of 2018 to 2019, Sambas Regency IOM has carried out its socialization function. However, if seen from the effectiveness of its function, the socialization has not been able to influence the policy implementation of the task force significantly. It is in line with the 
opinion of Musta'im (2019) stating that: "The obstacles are incomplete information, the TPPO Task Force that has not been running, and slow service, and this is what we are trying to do with the improvement of dominant services and the task force that does not yet have a pattern. Meanwhile, in handling cases, IOM uses case records requiring complete data. I cannot go to the field while the task force is there. The task force should have given the data to me as a representative of IOM. That is the real plot. In the TPPO Task Force, the flow has not yet run, and the Standard Operating Procedures have not been carried out. So, there are cases having no response."

This statement indicates the need for socialization from the IOM to provide in-depth information regarding the handling and mechanism of victim complaints when human trafficking occurs. Then, representatives from Sambas IOM also stated that there were socialization efforts carried out through the agendas of the organization, namely: (1) Mapping of patterns of handling human trafficking in Sambas Regency through collaboration with Universitas Gadjah Mada that had been carried out twice; (2) Providing support through task force coordination meetings every three months to strengthen Standard Operating Procedures and funding issues; (3) Conducting socialization in several post-migrant villages, such as Pemangkat and Jawai (the villages distributing migrants the most). The socialization involved around 50 villages and received a reasonably good response with the formation of task forces in the villages as the first treatment. However, the weaknesses lie in the data availability and the absence of village authority to identify data according to regulations; (4) Provision of information through the Information and Education Communication media (IEC) in handling cases; (5) Strengthening the role of law enforcement officers; (6) Attending workshops with the attaches of the Embassy of the Republic of Indonesia and Malaysia; (7) Supervising the handling of victims from the beginning to the end; (8) IOM provides support to the Department of Manpower and 93 village heads by providing information on handling human trafficking cases in several countries, such as Australia and Singapore (Mustafa, 2019).

In a nutshell, IOM has carried out the socialization function through several agendas that have been conducted, including the dissemination of complaints patterns by involving village heads in Sambas Regency. It also involves law enforcement agencies in strengthening efforts and participating in international workshops conducted by Indonesia and Malaysia. Undoubtedly, carrying out these agendas becomes crucial in providing institutional strengthening and education for the community delivered through their respective village heads. Hence, it is expected that the agenda can overcome human trafficking in Sambas Regency.

Furthermore, the interview with the victim revealed his limited knowledge about the conditions that must be met when he wants to travel abroad. He said he had no idea that the government requires its citizens to complete legal and complete correspondence when crossing the two countries' borders. The agent asked him to say that he would follow his parents to Malaysia to be allowed to enter the country (R/Victim, 2019).

The recruitment function of international organizations is used to invite or attract participants, both directly and indirectly. In the international political system, the recruitment process carried out by the organization can be direct, carried out by the organization concerned to the audience or participants face-to-face and in a persuasive manner. It was conducted to invite the audience to join the organization. The second recruitment process indirectly carried out by involving third parties acting as intermediaries.

An institution cannot stand up and run alone. Thereby, in achieving its goals or interests, another institution is required, carried out through member recruitment. IOM is one of the representatives assigned to Sambas Regency as an effort to deal with and handle human trafficking. The field studies disclosed that the presence of IOM representatives in Sambas was only through one staff member. It might lead to obstacles in achieving interests; therefore, member recruitment is required (Mustaim, 2019). 
IOM does not conduct recruitment to achieve its interests, but through cooperation with other parties. It was conveyed by the representative of IOM West Kalimantan that "... The cooperation has been carried out twice with Universitas Gadjah Mada, while other NGOs are like LBH" (Mustafa, October 2, 2019). So far, the collaboration undertaken by IOM has involved two institutions, the first is Universitas Gajah Mada, as an educational institution, in the effort to establish a case handling pattern. The cooperation is also carried out with the Legal Aid Institute (LBH) to assist victims until the court stage and provide the rights of the victims.

The role of IOM is more focused on coordination with the task force, especially BP2A, as IOM's representative office is located. Through this BP2A, paralegal was formed as an extension agent from the government to protect children and women in the form of handling cases occurring at the village level. A paralegal is a village institution given authority in the first attempt at handling cases involving women and children, such as violence or those related to juvenile delinquency. This paralegal is found in every village in Sambas Regency with seven members, where the formation was carried out by BP2A at the district level (Hasdi, October 3, 2019).

The formation of paralegals as the smallest legal container in the village and the first complaint agency for victims aims to protect women and children. Of course, the protection of women and children is not only focused on cases occurring in the village but all cases relating to victims from a particular village. Included in this case are human trafficking cases, where human trafficking victims can make the first complaint to a paralegal and will be followed up as appropriate. In this sense, paralegal functions as a form of legal aid for victims at the village level. Hence, the role of IOM is more on the effort of assistance as a follow-up of the treatment carried out by paralegals. Therefore, the recruitment carried out by the regency government and by IOM were based on the cooperation formed, such as IOM and Universitas Gadjah Mada cooperation, and IOM and LBH cooperation. Through cooperation and the role of paralegals, the collaboration will occur to handle and resolve cases.
However, from the existing cross-sectoral cooperation, several obstacles were found in resolving the phenomenon of human trafficking in Sambas Regency, even though the government has been very responsive in issuing regulations. The process of assisting victims in reintegration to help them rise economically and socially is the most common obstacle. Victims do not know what they need to do in the reintegration process, even though IOM and the local government have given understanding and socialization. It causes the slow achievement of IOM's interests in resolving cases of human trafficking in Sambas Regency.

The function of the transaction in the view of Michael Haas involves exchanging symbols, goods, and services between one party with another party. In international relations, many issues involve the transaction function of international organizations, one of which is the mobilization of migrant workers crossing the boundaries of sovereignty between countries (Haas, 1965). At present, human trafficking is a prominent issue, particularly among international relations reviewers. Therefore, the United Nations has sought to deal with the problem of smuggling illegal immigrants and human trafficking occurring in all parts of the world by establishing the International Organization for Migration (IOM), an organization focusing on the field of immigration. IOM is an intergovernmental organization that relies on funds from member countries to fund the mobilization of its work programs. Unlike the United Nations Children's Fund (UNICEF) and the United Nations High Commissioner for Refugees (UNHCR), IOM is not an organization under the auspices of the United Nations but has the status of an observer at the United Nations. However, IOM continues to work closely with UNICEF and UNHCR in carrying out its functions (www.dw.com, 2006).

Moreover, IOM also cooperates with member state governments, civil society, and the police to deal with migration challenges, encourage community economic development through migration, and promote the social welfare of migrants, their families, and communities (International Organization for Migration, 2019). Through its branch in West Kalimantan, Indonesia, 
IOM seeks to help victims of human trafficking living in the Indonesia-Malaysia border region, Sambas Regency. For the community living in the border, migration activities have become standard practice. However, seasonal activities can also cause various problems, especially regarding safety guarantees. In order for migrants to be assured of safety, IOM has emerged as an international organization with its efforts to increase public understanding of migration and issues that can jeopardize safety when migrating (Morawska, 2007). In this discussion, the main issue of migration is human trafficking.

In the case of human trafficking involving migrant workers in Sambas Regency, researchers found that IOM has carried out its transaction function through various technical services. It is reflected in Musta'im's statement as a representative of the Sambas Regency IOM “... if the victim wants to continue schooling or to build a business, IOM together with the Social Service will help make it happen" (Musta'im, 2019). The action indicates that IOM has tried to exchange services in the form of coordination with a related government agency to assist victims jointly.

However, in carrying out its transaction function, IOM also experienced constraints related to the funding budget. One of the roles of the task force is to have the authority to administer the budget related to the handling of cases. Thus, IOM's role here is only as a distributor. However, this function has not been able to run optimally because the coordination between the two still faces obstacles, especially the lack of a given budget. "...so far, the obstacle is on costing or implementation budget" (Musta'im, Personal Communication, October 2, 2019). This obstacle should be overcome immediately, thereby it will not reduce the function of IOM to handle human trafficking victims, especially in Sambas Regency.

In 2017, IOM and the police tried to handle a victim of trafficking. The victim came from a low-income family who depended their lives on an oil palm plantation. The victim also had become an illegal migrant smuggled to Malaysia to work as a household assistant (ART). This victim often received harsh treatment. Moreover, this victim did not receive a salary based on the previous victim did not receive a salary based on the previous agreement. High workloads and not given salary caused the victim to decide to quit working and return to his hometown. The harshness of life and the high expenses that should be incurred for daily necessities cause victim' parents to intend to sell their children to colleagues working in the same place. At that time, through information from paralegals, IOM and the police tried to pick the victim up from the palm oil plantation. The effort was successfully carried out, and the victim was able to return home. In addition to the victim, his brothers also received assistance from IOM and the Regional Government in fees and school equipment to prevent such a case from occurring (R/Victim, 2019).

Therefore, based on the theory of international organizations coined by Michael Haas in Ikbar (2014), IOM has carried out the transaction function as it should. First, as an organization, IOM can accommodate a variety of complaints in the community, especially regarding migration issues and migrant smuggling. It can be seen from the collaboration carried out by IOM and paralegals in every village in Sambas Regency that helped collect information related to victims. Then, IOM also formed a partnership with the police, a place to report criminal cases.

Second, IOM has a range of locations for mobilization spread worldwide, enabling it to invite countries to join in efforts to achieve the interests, namely the safety and welfare of migrants and their communities. Third, IOM's vision is to build international cooperation to provide humanitarian assistance and find solutions to immigration problems. Therefore, IOM upholds human values and seeks to create prosperity and ideal life for everyone, including migrants and their families, through programs and services to the community, especially in areas vulnerable to human trafficking cases.

This transaction function also allows IOM to coordinate with government agencies or task forces. The Head of the Immigration Post of Aruk said that "the Immigration Office does not provide shelter for human trafficking cases because it is the police who handle human trafficking cases. We have not handled trafficking cases, but we participate in the investigation process, 
helping both provide an expert witness and be a guest speaker" (Umar, Personal Communication, July 30, 2019). The role of immigration in handling human trafficking is to participate in investigations and as expert witnesses and a resource person. It looks back to the function of immigration as an institution issuing passports for migrant workers.

"... immigration has a prevention program for non-procedural Indonesian workers, we have non-procedural Indonesian migrant workers. There is a program from the center, only from the Directorate General, we carry it out, so we are more careful of people wanting to work abroad, or the term becomes a transit point, wherein Malaysia there are flights going directly to Kuala Lumpur, so there is a strong possibility" (Umar, Personal Communication, July 30, 2019).

Related to efforts to prevent the occurrence of human trafficking, immigration has a program on the prevention of non-procedural migrant workers who are the forerunners of illegal migrant workers. It is due to cases of human trafficking usually caused by illegal migrant workers who do not have documents following procedures established by the state (Umar, Personal Communication, July 30, 2019). Therefore, the role of the Immigration Office as an authorized agency in the examination of documents and the issuance of passports can prevent human trafficking. Undoubtedly, the transaction function of IOM as an international organization cannot be done unilaterally, but there must be a strong synergy between IOM and stakeholders in Sambas Regency. Thus, coordination between parties, both government agencies, IOM, and civil society, is required in preventing and handling human trafficking in Sambas Regency because it needs to involve the exchange of services realized through communication and coordination of all related parties to achieve common goals.

\section{CONCLUSION}

The articulation function has been carried out by IOM to tackle human trafficking cases in Sambas Regency. IOM carries out its functions by cooperating or coordinating through the delivery of programs that should be carried out by the task force at the regency level government regarding human trafficking or other migration issues. The role of the organization is as a means of coordination, supporting efforts to improve more dominant services to strengthen the task force and support the efforts of legal aid agencies when handling victims. Furthermore, IOM also seeks to improve services to the community, specifically related to human trafficking.

The function of aggregation of interests owned by IOM is an effort to harmonize to avoid gaps in the units in the task force. In their efforts to tackle human trafficking cases, international organizations should provide support as an effort to align interests by bridging and nurturing institutions; thus, each institution understands their respective duties. Moreover, these efforts aim to facilitate each of the relevant institutions to facilitate by assisting victims of human trafficking. However, this effort cannot be fully applied as there is no strong synergy from IOM and the task force existing in the ranks of the Regional Government. On the other hand, the task of the government through the task force is implementing existing policies, while IOM supports and oversees the performance of the task force. However, the role still experiences an imbalance.

Since its establishment as a regency representative at the end of 2018 to 2019, Sambas Regency IOM has carried out its socialization function. However, regarding the effectiveness of its function, the socialization has not been able to provide a significant influence on the policy implementation of the task force or the community. It is also due to other factors, including the condition of the community in Sambas Regency. IOM is one of the representatives assigned to Sambas Regency as an effort to deal with and handle human trafficking. The recruitment function is applied by cooperating and forming paralegals to coordinate with the task force.

IOM has carried out its transaction function through various forms of technical services and services such as assistance to the reintegration of victims. The action indicates that so far, IOM has tried to exchange services in the form of coordination with relevant government 
agencies to assist victims jointly. However, in carrying out its transaction function, IOM also experienced constraints related to the funding budget. One of the roles of the task force is having the authority in administering the budget related to the handling of cases.

This paper shows the role and efforts of IOM as an international organization in dealing with human trafficking in Sambas, West Kalimantan. Through this paper, it is expected that there will be stronger and more coordinating cooperation between the central and regional governments in collaborating with international organizations to deal with human trafficking as a form of obligation to protect the human rights of migrant workers and prevent transnational crime. The limitations of this study are the authors use the input functions of international organizations, namely the function of articulation, aggregation, socialization, recruitment, and transactions. While the output functions, such as making, implementing, and monitoring rules, are not the focus of this study. It is expected that further research can focus on the output function and analyze the role and function of IOM in dealing with human trafficking in other Indonesian regions.

\section{REFERENCE}

Alunaza, H. (2016). Kebijakan Pemerintah Brunei Darussalam Meratifikasi The WHO Convention on Tobacco Control Fakultas Humaniora Unida. Journal of Islam and Internation al Affairs Dauliyah, /(2). doi:http://dx. doi.org/10.21111/dauliyah.v1i2.599

Ambarwati, \& Wijatmadja, S. (2016). Pengantar IImu Hubungan Internasional. Malang: Cita Intrans Selaras.

Archer, C. (2001). International Organization Third Edition. New York: Routledge.

Arif, G. W. (2016). Peran International Organization for Migration (IOM) dalam Mengatasi Perdagangan Manusia di Indonesia Tahun 2010-2014. Jurnal Universitas Riau, 3(1), 1-15. Retrieved from https://jom.unri.ac.id/index.php/JOMFSIP/ar ticle/view/8773/84

Asfa, T. R. (2017). Analisis Peran International Organization Of Migration (IOM) dalam Menangani Kasus Perdagangan Manusia di Indonesia berdasarkan Prinsip-Prinsip Humani tarianisme. Retrieved from http://scholar.un and.ac.id/28946/5/FULL\%20DRAFT.pdf

Atem. (2017). Menelisik Fenomena Human Trafficking di Kaliman tan Barat.Jurnal Studi Gender dan Anak,4(1). 4(1), 32-37. doi:doi:https://doi.org/10.24260/raheema.v4i1.829

Badan Pemberdayaan Perempuan Kalimantan Barat. (2018). Perdagangan Orang Terutama Perempuan dan Anak di Kalimantan Barat. Pontianak: P2TP2A.
Badan Perencanaan Pembangunan Daerah Kabupaten Sambas. (2016). RPJMD Kabupaten Sambas Tahun 2016-2021. Retrieved from https://bappeda.sambas.go.id/edoc/down load.php?file=208-44-rpjmd-kab-sambas-2016-2021.pdf

Badan Pusat Statistik Kabupaten Sambas. (2019). Kabupaten Sambas dalam Angka 2018. ISSN: 0215-6784. Katalog: 1102001.6101. Pontianak: CV. Swadesi Harapan Masa. Badan Pusat Statistik Kabupaten Sambas. (2019). Statistik Daerah Kabupaten Sambas 2018. ISSN: 2622-0326. Katalog: 1101002.6101. Pontianak: CV. Swadesi Harapan Masa.

Badan Pusat Statistik Kabupaten Sambas. (2019). Statistik Kesejahteraan Rakyat Kabupaten Sambas 2018. Katalog: 4101002.6101. Pontianak: CV. Swadesi Harapan Masa.

Gunawan, W. (2018, August 13). Polres Sambas Ungkap Empat Kasus Perdangan Orang Selama 2018. Retrieved from Tribun News Pontianak: http://pontianak.tribun news.com/2018/08/13/polres-sambas-ungkap-em pat-kasus-perdagangan-orang-selama-2018

Haas, M. (1965, August). A Functional Approach to International Organization. The Journal of Politics, 27(3), 498-517 Retrieved from http://www.jstor.org/stable/2127737

Ikbar, Y. (2014). Metodologi dan Teori Hubungan Internasional. Bandung: Refika Aditama.

Jackson, R \& Sorensen, G. (2013). Introduction to International Relations Theories and Approaches. United Kingdom: Oxford University Press.

Meiser, J. W. (2018). Introducing Liberalism in International Relations Theory. Retrieved from https://www.e-ir.in fo/2018/02/18/introducing-liberalism-in-international-rela tions-theory/

Morawska, E. (2007). International Migration: Its Various Mecha nisms and Different Theories that Try to Explain It. Sweden: Malmö University Electronic Publishing.

Niko, N. (2018). Fenomena Human Trafficking in Person di Wilayah Perbatasan Kalimantan Barat. Pontianak: Jurnal Studi Gender dan Anak Vol IV (I).

Oktavian, A., \& et.al. (2018). Peran International Organization of Migration (IOM) dalam Menanggulangi Kasus Human Trafficking di Indonesia. Retrieved from Prosiding Senas POLHI ke-1 Universitas Wahid Hasyim Semarang: https://ww w. publikasiilmiah.unwahas.ac.id/i

Permana Adhinata, M. (2014). Kejahatan Perdagangan Manusia sebagai Human Security Issues di Indonesia 2005-2009. Jurnal Hubungan Internasional, 1(1), 1-13. Retrieved from https://ojs.unud.ac.id/index.php/hi/article/view/7858

Rudy, T. M. (2003). Hubungan Internasional Kontemporer dan Masalah-Masalah Global; Isu, Konsep, dan Paradigma. Bandung: Refika Aditama.

Sekretariat Gugus Tugas Pencegahan dan Penanganan TPPO. (2018). Pencegahan dan Penanganan Tindak Pidana Perdagangan Orang. Retrieved from https://www.kemenp ppa.go.id/lib/uploads/list/f3b9b-buku-laptah-2018.pdf

Sugiyono. (2011). Metode Penelitian Kuantitatif Kualitatif dan $R \& B$. Bandung: Alfabeta.

Sugiyono. (2015). Memahami Penelitian Kualitatif. Bandung: Alfabeta.

Sutan. (2016, November 18). Inilah Kantong Human Trafficking di Sambas. Retrieved from Suara Pemred Kalbar: https://ww w.suarapemredkalbar.com/berita/sam- 
bas/2016/11/18/inilah-kantong-perdagangan-manu sia-di-sambas

Welle, D. (2006). Peran Organisasi Migrasi Internasional (IOM). Retrieved fro https://www.dw.com/id/peran-organisasi-mi grasi-internasional-iom/a-2958059

Widowaty, Y. (2015). Kerjasama Negara-Negara ASEAN dalam Menanggulangi Kejahatan Transnasional Narkotika dalam Menghadapi MEA 2015. Prosiding Konferensi Nasional Asosiasi Program Pascasarjana Perguruan Tinggi Muham madiyah (Vol. 2).

Winarno, B. (2011). Isu-Isu Global Kontemporer (Vol. XVII). Yogyakarta: CAPS.

Wismayanti, Y. (2012). Perlindungan Anak Berbasis Komunitas di Wilayah Perbatasan. Jurnal Sosio Konsepsia, XVII(2). 